2. Г. Дриш, Витализм. Его история и система. M.: URSS, 2007. 280 с.

3. Р. Шелдрейк, Новая наука о жизни. М.: Рипол Классик, 2005. 352 с.

4. A. H. Maslow, Motivation and Personality. Harper \& Brothers, 1954. $411 \mathrm{c}$.

DOI https://doi.org/10.30525/978-9934-26-146-6-2

\title{
ОСОБЛИВОСТІ ФОРМУВАННЯ МОТИВАЦІЇ СПОРТИВНОї ДІЯЛЬНОСТІ
}

\author{
Дейнеко А. X. \\ кандидат наук з фізичного виховання та спорту, \\ дочент кафедри гімнастики, таниювальних видів спорту \\ ma хореографіi \\ Харківська державна академія фізичної культури
}

\section{Біленька I. Г.}

старший викладач кафедри гімнастики, танщювальних видів спорту mа хореографії

Харківська державна академія фізичної культури

Марченков М. К.

дочент кафедри гімнастики, танџювальних видів спорту ma хореографii

Харківська державна академія фізичної культури м. Харків, Україна

Метою роботи $\epsilon$ теоретичний аналіз наукової думки щодо формування мотивації спортивної діяльності, яка $\epsilon$ важливим питанням У роботі тренера. У рамках напрямку «спортивна психологія» проблема мотивації вивчена досить широко $[1 ; 2 ; 4 ; 5]$, розроблено підходи до класифікації мотивації спортсмена, а також визначені функції і виділені завдання спортивної мотивації, проте існує і ряд факторів, що становлять певні проблеми у вивченні даної теми. Сучасні психологи, вважають, що врахування особливостей професійної мотивації може серйозно вплинути на успішність діяльності, особливо в спорті [2; 5; 7]. 3 аналізу літературних джерел $[1 ; 4 ; 5 ; 8]$, присвячених даній проблемі, можна відзначити, що особливе місце в психологічному забезпеченні спортивної діяльності займає мотивація, що спонукає людину займатися спортом. На думку Трачук В.В. [7] мотивація - це система факторів, 
детермінуючих поведінку та пояснюючих активність людини. Він вважає, що мотиви - це спонукання до дії, пов'язаної із задоволенням потреб людини. Вони формуються на основі потреб і пов'язані 3 почуттям їх задоволення чи незадоволення. Тобто мотиви - це особистісні спонукання, які мають індивідуальні відмінності. На основі різноманітних критеріїв мотиви занять спортом класифікують: $з a$ спрямованістю на процесуальні мотиви (інтерес, задоволення тощо) та результативні (очікування нагороди, позитивні результати, наслідки перемоги тощо); за ступенем стійкості на ситуативні (короткочасні, що проходять) та стійкі (довгочасні, часто багаторічні); за зв 'язком із цілями спортивної діяльності на сенсоутворюючі (прямо пов'язані з метою) та стимули (наприклад, матеріальні стимули); за місием в системі «Інші Я» на індивідуальні (мотиви особистого самоствердження) та групові (патріотизм усіх рівнів, мотиви чесної змагальної боротьби й інші); за домінуючою установкою на мотивацію досягнення успіху (перевага мотивів на успіх, перемогу, навіть шляхом ризику) та мотивацію втечі від невдачі [8]. Загальновідомо, що блок мотивації утворюють потреби, мотиви і цілі спортивної діяльності.

Потреба - це така нужда організму, щодо якої він озброєний спеціальними механізмами ії виявлення та усунення. Іншими словами, потреба - це не тільки нужда, а й визначений засіб ії задоволення, що закріпився в процесі філо- та онтогенезу. Регулювання потреб є одним 3 найголовніших завдань у вихованні людини. Це стосується кількості та якості потреб. Заохочувати потрібно тільки ті з них, що сприяють розвитку творчих і психомоторних здібностей [7]. Вибір спортивної діяльності як засобу задоволення спочатку однієї, а потім комплексу потреб часто відбувається спонтанно. Г. Д. Горбунов [2] включає в цей комплекс наступні потреби: потреба в діяльності, активності, потреба в русі, потреба в реалізації рефлексів мети й свободи, потреба в суперництві, змаганні, самоствердженні, потреба бути в групі, спілкуватися, потреба в нових враженнях і ін. Необхідно зазначити, що задоволення потреб сприяє їх зростанню, а незадоволення - призводить до їх зникнення.

Мотив - це спонукання до певної активності, до задоволення потреби певним способом. 3 точки зору науковців [2; $5 ; 6 ; 7]$, потреба є джерелом активності, мотиви ж надають цій активності певний напрямок. Г.А. Кузьменко [6] підкреслює, що мотиви навчально-тренувальної діяльності можуть бути внутрішні та зовнішні. Зовнішні мотиви у спортсменів проявляються в наступному: по-перше, навчальнотренувальний процес як вимушена поведінка; по-друге, змагання як звичне функціонування; по-третє, спорт заради престижу і лідерства, по-четверте, 
прагнення опинитися в центрі уваги. На його думку - зовнішні мотиви мають як ділову складову, де результатом є заохочення, або покарання, так i змагальну, де дитина прагне самоствердитися на підставі успіху в порівнянні 3 товаришами та 3 самим собою [6]. Більше того, внутрішні мотиви $є$ найбільш сильними за рахунок стимулюючого потенціалу i відрізняються від зовнішніх більшою пов'язаністю з самою особистістю спортсмена, з його сутністю [6]. Тому у навчально-тренувальному процесі слід прагнути до становлення внутрішньої мотивації. Однак в ході змагальної діяльності провідною може стати зовнішня мотивація, коли спортсмен перемикається на виконання установок тренера [6]. Безсумнівно, мотиви спортивної діяльності відрізняються динамічністю проявів. Тобто в процесі тривалих занять спортом у одного й того ж спортсмена спостерігається закономірна зміна мотивів.

Мета (ціль) - це образ передбачуваного результату діяльності, або конкретного етапу. Тому цілі спортивної діяльності - це своєрідні віхи, які людина вибудовує в думках упродовж спортивної кар'єри. Отже, якщо мотиви визначають вибір шляху, напрямок руху, то цілі наскільки далеко і успішно спортсмен має намір пройти даним шляхом. Цілі завжди усвідомлювані і є підсумком уявної роботи, у процесі якої спортсмен намагається вирішити протиріччя між вимогами спортивної діяльності та власними можливостями, здатностями адаптуватися до цих умов і вимог. Таким чином, ціль виступає регулятором активності, впливаючи на вибір конкретних засобів досягнення бажаного спортивного результату [3].

3 метою формування тренувальної мотивації Г.Д. Бабушкін i Є.В. Кулагіна [1] пропонує створювати стійкий інтерес до занять, позитивний емоційний фон на тренуваннях, пояснювати значущість занять спортом в особистому житті для формування особистісного сенсу, ставити реально досяжні цілі і вчити ставити мету самостійно, формувати дружні відносини в команді, запобігати негативним психічним станам, підтримувати сформовані мотиваційні установки i створювати сприятливі умови для появи нових, використовуючи психологічні механізми «знизу вгору» і «зверху вниз». Для формування змагальної мотивації, на їх думку, необхідно забезпечити підготовленість до участі в змаганнях, виявити недоліки і сильні сторони суперників, поставити цілі відповідно до підготовки спортсменів, змоделювати суперників в тренувальній діяльності, актуалізувати мотиви участі в змаганнях.

Гуренко Ю.В. [3] засвідчує, що спортивна мотивація формується шляхом мотиваційної саморегуляції. У практиці використовують два психологічних механізму: безпосередня мотиваційна саморегуляція 
(шляхом логічного мислення) i опосередкована (через медитацію). Безпосередня мотиваційна саморегуляція вимагає формування у спортсмена вміння керувати думками і почуттями, формуванню ставлення до змагань, суперникам і перемозі, визначенню свого місця в спортивній діяльності. Медитація, як перебування у нерухомості i внутрішнє самопізнання представляється чимось протилежним спорту, що залучає в активну діяльність все тіло. Однак, все більше і більше професійних спортсменів практикують медитацію, щоб підвищити свою результативність, поліпшити психологічний та емоційний стан, зняти стрес, посилити увагу і зосередженість.

Таким чином, результати проведеного аналізу спеціальної літератури свідчіть про те, що мотивація навчально-тренувальної діяльності визначається як спонукання до діяльності та усвідомлювана причина, яка лежить у виборі дій і вчинків особистості спортсмена. Проте, блок мотивації (потреби, мотиви й цілі) спортивної діяльності є пусковим механізмом, що підтримує необхідний рівень активності під час тренування та змагання. Тому пошук шляхів формування мотивації навчально-тренувальної діяльності спортсменів $\epsilon$ важливим питанням у роботі тренера.

\section{Література:}

1. Бабушкин Г. Д. Кулагина Е.В. Психологическая совместимость и срабатываемость в спортивной деятельности. Омск : СибГАФК, 2001. $109 \mathrm{c}$.

2. Горбунов Г. Д. Психопедагогика спорта. Москва : Советский спорт, 2007. $296 \mathrm{c.}$

3. Гуренко Ю. В. Формирование мотивов учебной деятельности у подростков в учреждениях дополнительного образования в сфере физической культуры : дис. ... канд. пед. наук : 13.00.01; 13.00.04. Калининград, 2018. 143 с.

4. Дейнеко А. Х., Насонкіна О. Ю. Особливості формування процесу мотивації як значущої частини психологічної підготовки у спорті. Науковий часопис Національного педагогічного університету імені М.П. Драгоманова. Серія № 15. 2019. Випуск 4(113)19. С. 26-30.

5. Ильин Е. Мотивация и мотивы. Санкт-Петербург : Питер, 2011. C. $472-478$.

6. Кузьменко Г. А. Развитие интеллектуальных способностей подростков в условиях спортивной деятельности: теоретикометодологические и организационные предпосылки. Москва : Прометей, 2013. 532 c. 
7. Трачук В. В. Психологічна характеристика спорту як виду діяльності. URL : http://elartu.tntu.edu.ua/bitstream/lib/29707/6/ dyplom_Trachuk. pdf.

8. Фактори формування мотивації досягнення успіху. URL : http://bo0k.net/index.php?p=achapter\&bid=16404\&chapter $=$

DOI https://doi.org/10.30525/978-9934-26-146-6-3

\title{
КАТЕГОРІЯ «ДУША» В ІСПАНСЬКІЙ ПСИХОЛОГІЇ НА МЕЖІ ХІХ - ХХ СТОЛІТЬ
}

\author{
Зайченко Н. I. \\ доктор педагогічних наук, \\ професор кафедри загальної та прикладної психології \\ ПВНЗ «Інститут екології економіки і права» \\ м. Київ, Украӥна
}

Категорія «душа» - ключова категорія іспанської психології на межі XIX - XX століть. Психологія визначалася в той час як «наука про душу» i призначалася головним чином для пояснення сутності та устрою людської душі. У «Компендіумі психології, логіки й етики» (Мадрид, 1891 р.) викладача Сарагоського Інституту середньої освіти Л. Елейсальде Йзагірре (Luis Maria Eleizalde e Yzaguirre) наголошувалося: «душа - це первинна основа життя в тілесній органічній субстанції» $[1$, с. 9]; «розумна душа є субстанціональною формою людського тіла» [1, с. 138].

Зазначалося і про те, що душа - духовної природи, вона за сутністю незалежна від матерії. У «Компендіумі...» духовність душі пояснювалася таким чином. Людський розум пізнає велике розмаїття об'єктів, воно не може вражати виключно органи відчуття. Пізнання таких нематеріальних речей, як можливість, неможливість, право, обов'язок, справедливість, підвладне душі, яка функціонує незалежно від органів відчуття, яка існує віддільно від матерії. Доказом духовності душі виступає, на думку Л. Елейсальде Йзагірре, й те, що ііі унікальна здібність - воля, «господарка людських дій», $є$ «вільною», $\epsilon$ «потенцією незалежною від матерії» [1, с. 94-95].

У «Компендіумі психології, логіки і філософії моралі» (Валенсія, 1890 р.) викладача Валенсійського Інституту середньої освіти М. Поло Пейролона (Manuel Polo y Peyrolon) стверджувалося: «дух - це 